University of Nebraska - Lincoln

DigitalCommons@University of Nebraska - Lincoln

Faculty Publications: Department of Teaching, Department of Teaching, Learning and Teacher Learning and Teacher Education

Education

$10-2001$

\title{
Beliefs of Science Teachers Toward the Teaching of Science/ Technological/Social Issues: Are We Addressing National Standards?
}

Jon E. Pedersen

University of Nebraska-Lincoln, jpedersen2@unl.edu

Samuel Totten

University of Arkansas

Follow this and additional works at: https://digitalcommons.unl.edu/teachlearnfacpub

Part of the Teacher Education and Professional Development Commons

Pedersen, Jon E. and Totten, Samuel, "Beliefs of Science Teachers Toward the Teaching of Science/ Technological/Social Issues: Are We Addressing National Standards?" (2001). Faculty Publications: Department of Teaching, Learning and Teacher Education. 95.

https://digitalcommons.unl.edu/teachlearnfacpub/95

This Article is brought to you for free and open access by the Department of Teaching, Learning and Teacher Education at DigitalCommons@University of Nebraska - Lincoln. It has been accepted for inclusion in Faculty Publications: Department of Teaching, Learning and Teacher Education by an authorized administrator of DigitalCommons@University of Nebraska - Lincoln. 


\title{
Beliefs of Science Teachers Toward the Teaching of Science/Technological/Social Issues: Are We Addressing National Standards?
}

\author{
Jon E. Pedersen \\ University of Oklahoma \\ Samuel Totten \\ University of Arkansas
}

\begin{abstract}
As science educators, we must view the changing nature of society brought on by technology and the global nature of society as an impetus to reexamine the nature of science instruction. We have been bestowed with the responsibility to educate students on a variety of topics that less than two decades ago did not exist. Many of these social issues are controversial in nature and are directly linked to the local, regional, national, and global communities in which we exist. However, including these social issues in the extant curriculum of science has, at best, been limited. This is true even though the National Science Education Standards specifically indicate that science and technology, as well as science in personal and social perspectives, are integral to science education. The following study examines a group of science teachers' beliefs about the implementation of controversial social/technological issues in the extant science curriculum. Indications are that teachers believe that social issues are important to study, yet lack the support from their communities to teach social issues.
\end{abstract}

Keywords: science, technology, society, social issues, controversial issues, science education, standards

S ocial/technological issues, many of which are controversial, are at the forefront of daily life. A mere sampling from the past decade provides some evidence of that: the extinction of numerous species of animals and plants, global warming, genocide in Iraq using biological weapons, and deforestation across the globe. Reform efforts such as Project 2061: Science for All Americans
(American Association for the Advancement of Science, 1989) encourage science teachers to weave social and technological issues within the fabric of the science curriculum. The National Science Standards (National Research Council [NRC], 1996) and standards for the preparation of science teachers (National Science Teachers Association [NSTA], 1998) also strongly advocate the use of Science/Technology/Society (STS) issues within the curriculum. For example, the National Science Education Standards (NRC, 1996) assert that "science in personal and social perspectives ... are an important purpose of science education" (p. 107). Furthermore, NSTA (1998) guidelines for the preparation of science teachers specifically indicate that

the program [should] prepare candidates to relate science to the daily lives and interests of students and to a larger framework of human endeavor and understanding. The context of science refers to:

- Relationships among systems of human endeavor including science and technology.

- Relationships among scientific, technological, personal, social and cultural values.

- Relevance and importance of science to the personal lives of students. (p. 461)

NSTA (1998) further recommends that

the program [should] prepare candidates to relate science to the community and to use human and institutional resources in the community to advance the education of their students in science. The social 
context of science teaching refers to:

- Social and community support network within which occur science teaching and learning.

- Relationship of science teaching and learning to the needs and values of the community.

- Involvement of people and institutions from the community. (p. 464)

Yet indications are that little is being done in the classrooms to engage and immerse students in the rigorous understanding of the complexity of these interactions (Pedersen \& Totten, 1994). This study sets out to examine the beliefs of science teachers concerning the implementation of controversial social/technological issues in the extant science curriculum. The significance of this study centers on the value of understanding teachers' beliefs and utilizing these beliefs in assisting in current reform efforts.

\section{Social Issues as a Context for Science}

The nature of the society in which we live is changing. Current societal norms expose our children to countless social issues that did not exist even 10 years ago. Although not all of these social issues are linked to science and technology, many are. Schools today, and especially science curricula, have an obligation to immerse students in the rigorous study of the interrelationship of STS and to assist them in understanding the varied and significant ramifications of such social issues. Many science educators propose that STS issues are an appropriate avenue by which controversial social technological issues should be incorporated into the classroom (Hofstein \& Yager, 1982; Pedersen, 1992; Roy, 1985; Rubba \& Wiesenmayer, 1985; Yager, 1993). For example, Hofstein and Yager advocate a science classroom where the content would be selected on its value in assisting students in dealing with real world problems.

The study of complex issues faced by society, of which there may or may not be a consensus as to the cause and/or solution to the problem and which in fact may be controversial (Totten, 1992), is supported by many current reform efforts such as Project 2061 (American Association for the Advancement of Science, 1989), the NRC (1996), and the NSTA (1998). As Simmons (1993) comments, "The teaching of science/technology/society (STS) topics to students is advocated by members of the science education community as a critically needed infusion of the reform of science teaching and curriculum" (p. 1). This is only underscored by the inclusion of STS issues as part of the National Science Education Standards (NRC, 1996) and the National Association for the Accreditation of Teacher (NSTA, 1998) guidelines. In fact, as Bragaw (1993) indicates, all of the present or proposed science education improvement projects have social and behavioral component to them, and some profess STS orientation for at least part of the design.

Scientific literacy has emerged as a central role of science education, which includes STS themes as a part of the definition. As aptly pointed out by Project 2061 (American Association for the Advancement of Science, 1989), a scientifically literate person is one who is aware of the strengths, limitations, and interdependency of science, mathematics, and technology; understands the principal scientific concepts of science; is familiar with the natural world and understands its unity and diversity; and is able to use scientific knowledge and scientific ways of thinking to advance social and individual purposes. Not only should students study the countless ways scientific and technological developments have enhanced our lives, but they should learn about the tangle of interconnected consequences that spin off such developments. Only then will they truly comprehend the symbiotic and dynamic relationship between science, technology, and society (Gilliom, Helgeson, \& Zuga, 1992). However, research completed during the past decade reflects the ignorance of the general population toward and understanding of science. Morris Shamos (quoted in Rachlin, 1988) states that as much as $95 \%$ of society is ignorant about science. This evidence is clearly supported in regard to public school children by the extensive analysis of 9-, 13-, and 17-year-olds' lack of knowledge or understanding of scientific concepts (National and State Department of Education, 1996). A focus must be resolved for science education that relates the study of scientific principles to the personal lives of the students and the society in which they live. It may no longer be possible to draw a clear line between the intellectual demands of good science and the ethical demands of the good life (Toulmin, 1979).

In addition to the building of scientifically literate citizens, various researchers have found that the study of STS or using social and technological issues as the context of the study of school science affects the attitudes and achievement of students. Learning science in an STS context enhances creativity, improves attitudes, increases academic achievement, and expands the use of science in daily life (Aikenhead, 1990; Bybee, 1987; Bybee \& Mau, 1986; Penick \& Yager, 1986; Yager, 
1988). For example, Aikenhead (1990) indicates that the concrete connections between the academic science content and the student's everyday world make the academic science content more interesting to learn for $80 \%$ of the students. Other researchers indicate that the study of social issues such as nuclear energy, population growth, and environmental stresses encourages interest, critical and high-level thinking, as well as problem-solving and decision-making capacity for a democratic system in students (Zoller, Donn, Wild, \& Beckett, 1991).

\section{Teacher Beliefs}

Even with the perceived and documented advantages of the implementation of STS issues (of which many are controversial in nature and directly linked to the local, regional, national, and global communities in which we live), there seems to be a taboo or stigma tied to the teaching of these topics in science classrooms. As McGinnis (1993) reports, "Some controversial topics are perceived by some teachers to be taboo in their local cultures and are not taught" (p. 21). Even though there is a movement afoot nationally and teachers indicate that STS themes should be a part of the school science program (Bybee, 1993), teachers, administrators, parents, teacher educators, and other stakeholders continue to debate whether social issues should be included within the extant curricula. Others indicate that the study of controversial social/technological issues is found mainly in the social studies curriculum (Mitchener \& Anderson, 1989). Still others (McGinnis, 1993) indicate that some of these issues are too controversial to teach in the local culture. It seems that it would be critical to consider the venue or context in which social issues are selected. That is, local culture could play a key role in what is controversial.

Aikenhead (1988) indicates that $73 \%$ of students surveyed indicated that the main sources of their ideas about scientists and the social and technological contexts of science were television, films, magazines, and books. Science classes as a source of ideas only ranked a distant $10 \%$ and only two percentage points above family members and English or social studies classes. In a similar type of study, Pedersen and Totten (1994) found that the sciences (biology, chemistry, physics, and earth sciences) were at the place least likely for students to study social issues.

Many students have developed false conceptions and beliefs about science, scientists, technology, engineers, and research and development in these fields (Aikenhead, 1985, 1989; Ryan, 1987). In addition, Lawson and Worsnop (1992), investigating the effects of culture/science conflicts, found that certain cultural beliefs (in this case, special creation) hindered the acquisition of science beliefs. In essence, they found that beliefs, rather than declarative knowledge, were related to the acquisition of scientific beliefs. It would appear that findings such as these, as well as other research on culture and acquisition of scientific beliefs and knowledge, would indicate that when cultural beliefs conflict in the science classroom then learning may be impeded. As related by the previous research, teachers seem to say that they believe in the value and worth of STS as a context for the study of science, but their activities and practice do not match these stated beliefs.

It is recognized that teachers' beliefs do influence the way that the curriculum is interpreted and implemented (Mitchener \& Anderson, 1989; Zoller, Dunn, Wild, \& Beckett, 1991). Beliefs are defined as statements considered to be true or false, regardless of whether they are, which defines expectations as explicit or implicit cognitive predictions with varying degrees of strength and certainty (Borphy \& Evertson, 1981). In relation to this view, Benson (1989) states that the gap between what teachers say they believe about the nature of science and what they do in practice is apparent. When confronted with the apparent contradictions between their beliefs and practice, teachers cite external constraints (e.g., peers, administrators, state mandates, etc.) as a major factor influencing their practice. This could be similarly related to the view that the teachers hold of STS. That is to say, although teachers hold particular beliefs about the role of STS, external constraints may be viewed by the teachers as preventing them from implementing their beliefs. As Jackson (1993) states, STS themes may be perceived to be too controversial in the local culture by the teachers. Hence, a contradiction occurs between the teachers' beliefs and the belief system of the culture of the school and community.

In relation to this, teachers entering a school are immersed in a culture that is unique to the school itself. These new teachers enter into the community (i.e., the school) where canonical knowledge (commonly shared and accepted knowledge) from the more experienced and competent teachers (McGinn, Roth, Boutonne, \& Woszczyna, 1995) may reaffirm or contradict their own beliefs. As Bruner (1985) indicates, "Members of a culture learn from their tutors, the vicars of their culture, how to understand the world ... that consists of con- 
ceptually organized, rule bound beliefs systems about what exists, about how to get to goals, about what is to be valued" (p. 32). Therefore, teachers' beliefs may be impacted by the cultural milieu of the community through canonical knowledge shared among peers. In essence, the community's constraints may affect the beliefs of the teacher. Tobin (1994) concurs that constraints can be obstacles to change in teachers' practices. When constraints act as myths for a culture (i.e., social expectations, time, scarce resources, control), teachers may suppress any changes considered, even when teachers are strongly committed to personal change (Tobin, 1991; Tobin, Tippins, \& Hook, 1992). With this in mind, we must heed the caution of O'Loughlin (1990), who states that teacher beliefs are not simple and may not have a direct bearing on teachers' actions.

\section{Objective/Purpose}

The objective of this study is to examine teachers' beliefs and perceptions about the STS issues, which may be controversial in the extant curriculum. Teachers were asked to about their ideas relating to the teaching of social issues in areas such as: support for teaching controversial social/technological issues, sources of information on controversial social/technological issues, and specific controversial social/technological issues they believe are of importance to include in the extant curriculum.

Several aspects of teachers' beliefs about curriculum and textbook usage, personal beliefs about controversial social/technological issues, specific social issues and their importance, outside influences, and teacher-student relations were investigated.

\section{Subjects}

Thirty-seven science teachers who had attended a summer or spring workshop on the improvement of science teaching at a major southeastern land grant institution participated in the study representing rural, urban, and suburban areas. It should be noted that the workshops did not place an emphasis on the usage of controversial social/technological issues.

\section{Design/Procedures}

The instrument used for this study was a 44-item Attitudes and Beliefs survey that had seven subsections (demographic data, curriculum and textbooks, personal beliefs, outside influences, teacher/student relationships, support for the implementation of social/technological issues, and specific social issues). The first section asked respondents to indicate general demographic information. The next five subsections were Likert-type scales asking the participants to indicate their particular beliefs. The final subsection asked the respondents to rank-order the importance of specific social issues. The principal investigator developed the survey and a panel of experts was utilized to examine the instrument. During the process, 11 items from the original survey were viewed by the panel of experts as ambiguous and/or redundant. Based on these recommendations, all 11 items were deleted from the original instrument. After making the deletions, the instrument was used in its present state of 44 items.

The instrument was given to all 37 participants of the two workshops. Individuals were selected for the workshops based on an application process that selected science teachers who had an interest in improving their science teaching methodologies. Of those attending and receiving the instrument, 32 were returned in a completed form for a return rate of $86 \%$.

After a period of approximately 1 month, $50 \%$ of the respondents were sent the same 44-item survey and asked to complete it again. These surveys were used in a comparison with the original data set as a means to establish the reliability. The test-retest method employed, using correlation coefficients, indicated that the instrument had an $r$ value of .85. Based on this information, it was determined that the instrument was reliable.

\section{Results}

The majority of the respondents to the current project were representative of the region in which the sample was drawn (see Table 1 for demographic data).

For the analysis and reporting of the results, the 40 items contained in section 2 of the Attitudes and Beliefs Survey were divided into broad categories: curriculum and textbooks, personal beliefs, beliefs about social issues, outside influence/constraints, teacherstudent relationships, importance of social issues, and sources of social issues. These categories represent several aspects of the teaching of social issues. Therefore, it is necessary to examine the data from each these categories separately to gain a complete understanding of the attitudes and beliefs of the respondents in this study. 
Table 1. Demographic Data

\begin{tabular}{|c|c|c|}
\hline Nun & ber & Percentage \\
\hline \multicolumn{3}{|l|}{ Gender } \\
\hline Male & 14 & 43.75 \\
\hline Female & 18 & 56.75 \\
\hline \multicolumn{3}{|l|}{ Race } \\
\hline African American & 0 & 0.0 \\
\hline Asian & 0 & 0.0 \\
\hline Caucasian & 32 & 100.0 \\
\hline Hispanic & 0 & 0.0 \\
\hline Native American & 0 & 0.0 \\
\hline Other & 0 & 0.0 \\
\hline \multicolumn{3}{|l|}{ Age (years) } \\
\hline 21 to 30 & 2 & 6.25 \\
\hline 31 to 40 & 14 & 43.75 \\
\hline 41 to 50 & 12 & 37.5 \\
\hline 51 to 60 & 4 & 12.5 \\
\hline Older than 60 & 0 & 0.0 \\
\hline \multicolumn{3}{|l|}{ Education } \\
\hline Bachelor of arts & 2 & 6.25 \\
\hline Bachelor of science & 14 & 43.75 \\
\hline Master of scienceleducation & 16 & 50.0 \\
\hline Doctor of philosophy/education & 0 & 0.0 \\
\hline \multicolumn{3}{|l|}{ Years teaching } \\
\hline Preservice & 2 & 6.25 \\
\hline 0 to 2 & 2 & 6.25 \\
\hline 3 to 5 & 4 & 12.5 \\
\hline 6 to 10 & 4 & 12.5 \\
\hline 11 to 15 & 8 & 25.0 \\
\hline 16 to 20 & 10 & 31.25 \\
\hline 20 or more & 2 & 6.25 \\
\hline
\end{tabular}

\section{Curriculum and Textbooks}

The items in this category attempted to gain insights into the curriculum that is currently being used in the classroom. More specifically, the goal was to obtain insights as to the teachers' development of their curriculum as well as ascertaining whether social issues were included in the curriculum. The results from this section were surprising and represent the antithesis of what the investigators of this study anticipated. It would appear that the majority of respondents have a belief that including social issues in their curriculum is important. More than $70 \%$ of the respondents strongly agreed or agreed that social issues should be integrated into the curriculum. Data from this category also show that the respondents have the freedom to develop their own curriculum with little or no outside influence. But despite this freedom, more than $68 \%$ reported that their curriculum was derived from a textbook. This factor becomes even more surprising coupled with the fact that more than $81 \%$ of the respondents stated that textbooks do not adequately cover social issues yet, and more than $65 \%$ of the teachers reported that the current science curriculum being taught in their schools provides students with valuable information on social issues. In addition, the respondents were split evenly on whether their lesson plans incorporated social issues that the students were interested in (see Figure 1 and Table 2).

Another apparent contradiction that becomes evident from the data is that more than $56 \%$ of the respondents stated that they incorporate social issues into their curriculum. The question that arises from this belief that teachers hold is how? How are social issues incorporated in the curriculum if nearly $69 \%$ of the teachers report that their curriculum is based on a textbook that does not adequately cover social issues and is not presenting information that students are interested in learning about?

\section{Personal Beliefs}

The majority of the respondents indicate that they believe that teaching social issues is important. More than $80 \%$ stated that they would feel comfortable discussing social issues in the classroom. They also stated that they could effectively teach social issues, are competent to teach social issues, and are adequately prepared to teach social issues (see Figure 2 and Table 3). Also, more than $55 \%$ believed that teaching social issues is just as important as teaching math, science, social studies, and so forth. But it is important to note that fewer than $13 \%$ of the respondents believed that teaching social issues is not as important as teaching the content related to specific disciplines, and more than $30 \%$ had no opinion.

Data from this category also suggest that more than $68 \%$ of the respondents from this pilot study believe that teachers bear too much responsibility in educating students about social issues. This point may be related to why some teachers do not believe that social issues should be taught in the classroom. They believe that it is not their job to educate students about social issues, but to educate students about the textbook content of their discipline. The respondents also indicated that teaching social issues in their classrooms would create controversy in their schools. This may also be a key reason why many teachers do not incorporate social issues into the curriculum. 


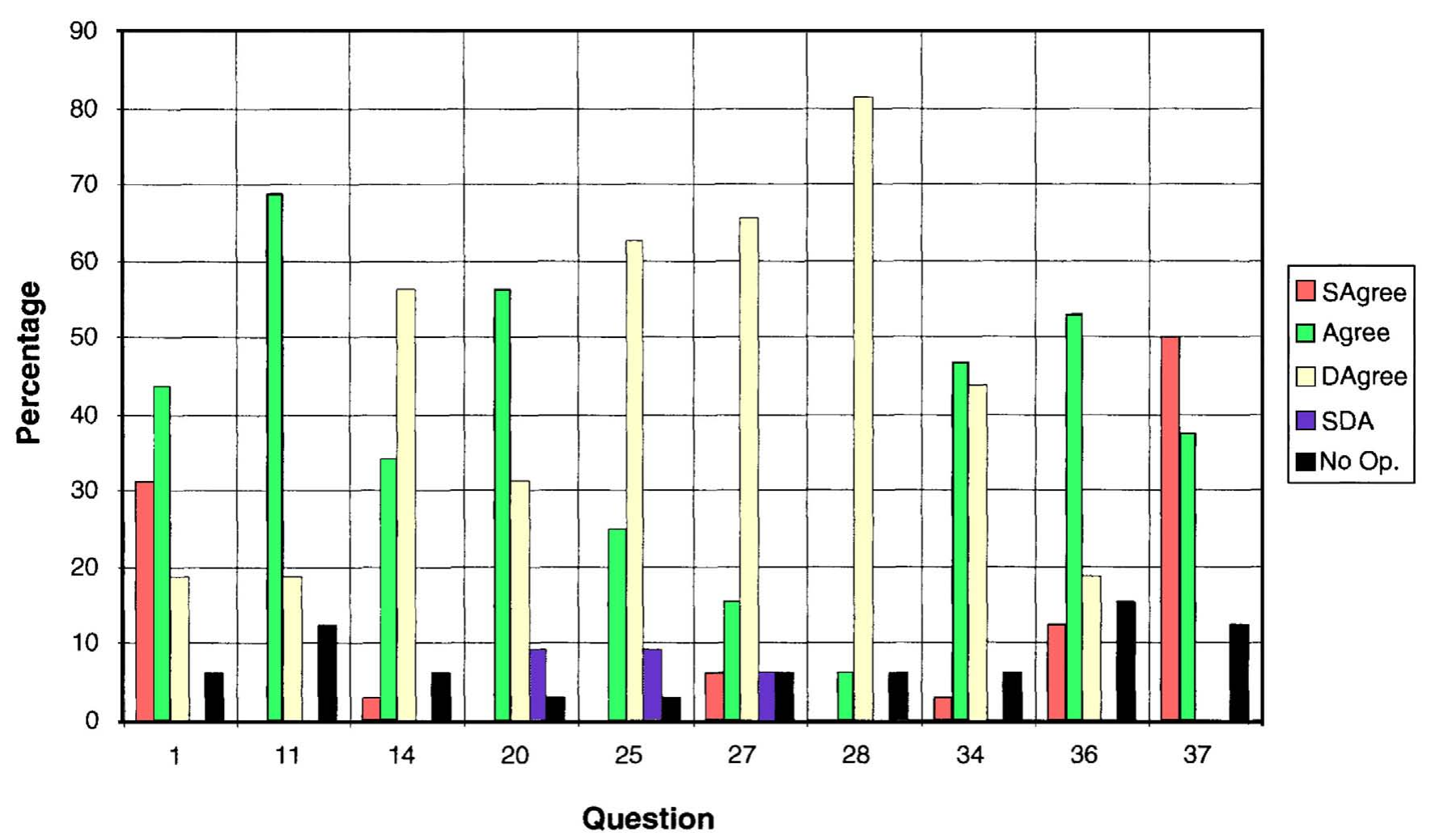

Figure 1. Curriculum and Textbooks

SAgree $=$ strongly agree, DAgree $=$ disagree, $\mathrm{SDA}=$ strongly disagree, and No Op. = no opinion. Statements are as follows:

1. I believe that social issues should be integrated into the current science curriculum.

11. The majority of my curriculum is derived from a textbook.

14. The current science curriculum being taught in my school provides students with valuable information on social issues.

20. My current curriculum includes social issues.

25. I must follow a very strict curriculum set up by the district.

27. Science/technology/society (STS) has been implemented in my present curriculum.

28. I feel that textbooks adequately cover social issues.

34. My lesson plans incorporate social issues that my students are interested in.

36. I consider the backgrounds and cultures of all my students when preparing lessons concerning social issues.

37. My curriculum integrates current world affairs.

\section{Specific Social Issues}

The majority of the responses in this category indicated that teachers hold beliefs that teaching certain social issues is important. Surprisingly, the respondents provided very positive opinions about the teaching of social issues that are controversial in nature, such as environmental studies, HIV/AIDS, censorship, and abortion rights. These data are consistent with previous data reported in the preceding sections. More specifically, the respondents consistently indicated a belief that teaching social issues is important. Furthermore, indications are that these teachers are open-minded in teaching about social issues (see Figure 3 and Table 4).

\section{Outside Influences/Constraints}

In this section, items focused on the outside influences and/or constraints that are a part of teaching, namely: administrators, peers, community, and so forth. The goal of the investigators was to examine whether the teachers held a belief that these outside influences were constraints to the implementation of social issues in the science curriculum. More than $74 \%$ of the teachers reported that they have their principals' support for trying new ideas in the classrooms. At the same time, $75 \%$ of the teachers believed that they are appreciated and respected by the administration. Despite these positive beliefs, this section of the survey also indicated some disheartening information. 
Table 2. Curriculum and Textbooks

\begin{tabular}{|c|c|c|c|c|c|c|c|c|c|c|}
\hline \multirow[b]{2}{*}{ Statement } & \multicolumn{5}{|c|}{ Percentage per Item } & \multicolumn{5}{|c|}{ Responses per Item } \\
\hline & $\begin{array}{r}\text { Strongly } \\
\text { Agree }\end{array}$ & Agree & Disagree & $\begin{array}{l}\text { Strongly } \\
\text { Disagree }\end{array}$ & $\begin{array}{r}\text { No } \\
\text { Opinion }\end{array}$ & $\begin{array}{r}\text { Strongly } \\
\text { Agree }\end{array}$ & Agree & Disagree & $\begin{array}{l}\text { Strongly } \\
\text { Disagree }\end{array}$ & $\begin{array}{r}\text { No } \\
\text { Opinion }\end{array}$ \\
\hline 11 & 0.00 & 68.75 & 18.75 & 0.00 & 12.50 & 0 & 22 & 6 & 0 & 4 \\
\hline 14 & 3.12 & 34.38 & 56.25 & 0.00 & 6.25 & 1 & 11 & 18 & 0 & 2 \\
\hline 20 & 0.00 & 56.25 & 31.25 & 9.38 & 3.12 & 0 & 18 & 10 & 3 & 1 \\
\hline 28 & 0.00 & 6.25 & 81.25 & 0.00 & 6.25 & 0 & 2 & 28 & 0 & 2 \\
\hline 34 & 3.12 & 46.88 & 43.75 & 0.00 & 6.25 & 1 & 15 & 14 & 0 & 2 \\
\hline 36 & 12.5 & 53.12 & 18.75 & 0.00 & 15.63 & 4 & 17 & 6 & 0 & 5 \\
\hline 37 & 50.0 & 37.50 & 0.0 & 0.00 & 12.50 & 16 & 12 & 0 & 0 & 4 \\
\hline
\end{tabular}

Statements are as follows:

1. I believe that social issues should be integrated into the current science curriculum.

11. The majority of my curriculum is derived from a textbook.

14. The current science cumculum being taught in my school provides students with valuable information on social issues.

20. My current curriculum includes social issues.

25. I must follow a very strict curriculum set up by the district.

27. Science/technology/society (STS) has been implemented in my present curriculum.

28. I feel that textbooks adequately cover social issues.

34. My lesson plans incorporate social issues that my students are interested in.

36. I consider the backgrounds and cultures of all my students when preparing lessons concerning social issues.

37. My curriculum integrates current world affairs.

Only $18 \%$ of the teachers indicated that they are thoroughly supported by faculty and staff members on teaching social issues. Conversely, nearly $41 \%$ of the respondents had no opinion on whether they receive support from their coworkers. This important factor may be still another reason why some teachers are apprehensive when considering integrating social issues into their curriculum.

Another alarming factor is that the responses for the statement, "I feel that I would be supported by the parents of my students on teaching social issues in my classroom," were very mixed. Less than $50 \%$ of the teachers believed that they had the parents' support for the inclusion of social issues (see Figure 4 and Table 5). In addition, the data in this section also provided information in regard to the preservice and in-service programs in which these teachers participated. The data indicated that the teachers held a belief that their preservice and in-service programs did not adequately prepare them for the teaching of social issues.

\section{Teacher-Student Relationship}

Obviously, it is important for the teachers and students to be able to communicate with one another. It is through communication that teachers can enhance the educational process. The majority of the respondents reported having a positive relationship with their students. They believe that their students want to learn about social issues, and teachers and students feel comfortable communicating about these social issues with one another. All of the respondents indicated that they have a positive impact on their students' lives. All of the respondents in this category indicated that they have an obligation to teach students how to become responsible citizens (see Figure 5 and Table 6).

\section{Other Issues}

The last three sections of the survey provided information on the specific social issues teachers felt should receive the most to the least amount of attention in school. It should be noted that there was not a way that the investigators could include the full gamut of social issues in their list. With that in mind, the investigators attempted to include social issues that were relevant to science, as well as broad and current. Section 4 of the survey examined the teachers' sources of information on social issues. Again, as in the previous section, the investigators could not include the full gamut of sources. Therefore, the results are based on those sources that were preselected. The last section examined the level of support that the teachers received from administrators, faculty/staff, peers, students' parents, and the com- 


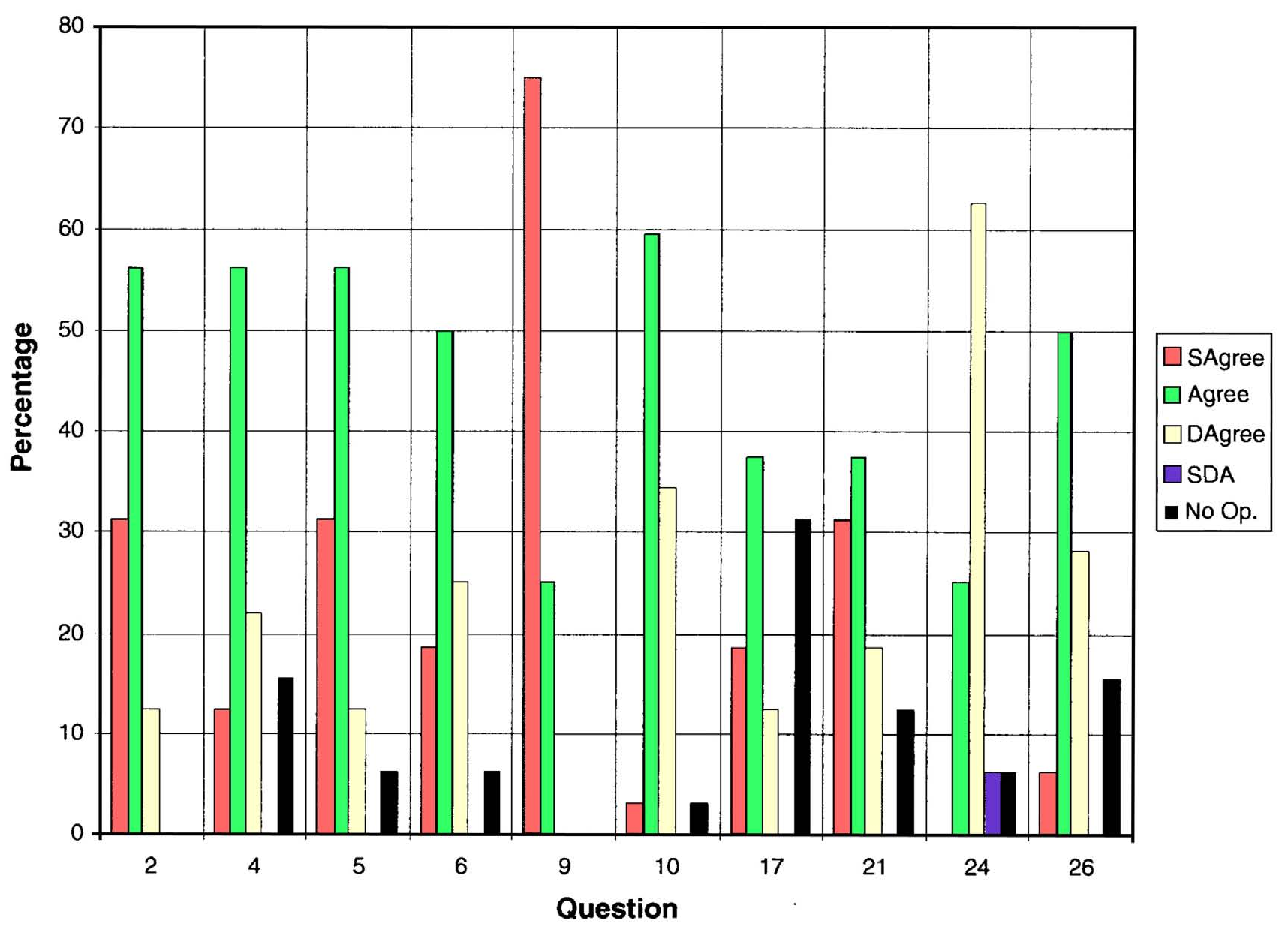

Figure 2. Personal Beliefs

SAgree $=$ strongly agree, DAgree $=$ disagree, $\mathrm{SDA}=$ strongly disagree, and No Op. $=$ no opinion. Statements are as follows:

2. I feel comfortable teaching and discussing social issues in the classroom.

4. I feel that I could effectively teach social issues.

5 . I believe that social issues should be taught in schools.

6. I feel competent in my abilities to teach social issues.

9. I feel competent in the subject area(s) in which I am presently teaching.

10. I feel adequately prepared to teach social issues.

17. Teaching social issues is just as important as teaching math, science, social studies, and so forth.

21. I feel that teachers bear too much responsibility for educating students on social and ethical issues in schools today.

24. I have a definite anxiety toward discussing social issues with my students.

26. I feel that teaching social issues would create controversy within the school.

munity at large, which helps in corroborating previous questions responded to in section 2 of this survey.

The teachers rated such issues as sex education, substance abuse, and the environment high on the list of social issues they felt were the most important to be taught. The teachers also indicated that they glean the majority of their information about social issues from newspapers, television, and radio. As far as support from administrators, faculty/staff, peers, and so forth, teachers reported that they received a moderate level of support from these individuals. However, it is interesting to note that nearly $60 \%$ of the teachers indicated that they received low sup- port for the teaching of social issues by their community (see Figures 6, 7, and 8, and Tables 7, 8, and 9).

\section{Discussion}

The investigators believe that coming to understand the teachers and the teachers' actions is critical in the cycle of reform. Without knowledge of how one implements and acts on new ideas, the new ideas themselves become meaningless if they are acted on in a trite manner. All educational research has seen reform efforts 
Table 3. Personal Beliefs

\begin{tabular}{|c|c|c|c|c|c|c|c|c|c|c|}
\hline \multirow[b]{2}{*}{ Statement } & \multicolumn{5}{|c|}{ Percentage per Item } & \multicolumn{4}{|c|}{ Responses per Item } & \multirow[b]{2}{*}{$\begin{array}{r}\text { No } \\
\text { Opinion }\end{array}$} \\
\hline & $\begin{array}{r}\text { Strongly } \\
\text { Agree }\end{array}$ & Agree & Disagree & $\begin{array}{l}\text { Strongly } \\
\text { Disagree }\end{array}$ & $\begin{array}{r}\text { No } \\
\text { Opinion }\end{array}$ & $\begin{array}{l}\text { Strongly } \\
\text { Agree }\end{array}$ & Agree & Disagree & $\begin{array}{l}\text { Strongly } \\
\text { Disagree }\end{array}$ & \\
\hline 4 & 12.50 & 56.25 & 21.88 & 0.00 & 15.62 & 6 & 18 & 7 & 0 & 5 \\
\hline 5 & 31.25 & 56.25 & 12.50 & 0.00 & 6.25 & 10 & 189 & 4 & 0 & 2 \\
\hline 6 & 18.75 & 50.00 & 25.00 & 0.00 & 6.25 & 6 & 16 & 8 & 0 & 2 \\
\hline 17 & 18.75 & 37.50 & 12.50 & 0.00 & 31.25 & 6 & 12 & 4 & 0 & 10 \\
\hline 21 & 31.25 & 37.50 & 18.75 & 0.00 & 12.50 & 10 & 12 & 6 & 0 & 4 \\
\hline 24 & 0.00 & 25.00 & 62.50 & 6.25 & 6.25 & 0 & 8 & 20 & 2 & 2 \\
\hline 26 & 6.25 & 50.00 & 28.12 & 0.00 & 15.63 & 2 & 16 & 9 & 0 & 5 \\
\hline
\end{tabular}

Statements are as follows:

2. I feel comfortable teaching and discussing social issues in the classroom.

4. I feel that I could effectively teach social issues.

5 . I believe that social issues should be taught in schools.

6. I feel competent in my abilities to teach social issues.

9. I feel competent in the subject area(s) in which I am presently teaching.

10. I feel adequately prepared to teach social issues.

17. Teaching social issues is just as important as teaching math, science, social studies, and so forth.

21. I feel that teachers bear too much responsibility for educating students on social and ethical issues in schools today.

24. I have a definite anxiety toward discussing social issues with my students.

26. I feel that teaching social issues would create controversy within the school.

come and go over the years. One must ask, Why? If we are doing our best to research and understand how children come to know and understand science and how teachers teach, then what is missing? Why is it that we keep getting what we have always gotten in terms of the implementation of reform efforts and classroom practice? As an example, social issues or STS as a reform has been supported and been part of most modern day reforms (Bragaw, 1993), yet as Totten and Pedersen (1994) show, students report little knowledge and involvement in the actual study of social issues. This becomes even more an issue as one examines the NRC's National Science Education Standards (1996) and the NSTA's (1998) standards for the preparation of science teachers.

This study is an attempt at initiating the first steps in a long search into teachers' beliefs and the possible constraints associated with their beliefs when it comes to the implementation of social issues. Even though the majority of the respondents indicated a belief in the teaching of social issues (more than 50\% stated that they would feel comfortable discussing social issues, and most indicated that they could effectively teach social issues, are competent to teach social issues, and are adequately prepared to teach social issues), only $37.5 \%$ believed that teaching social issues is just as important as teaching the content.
As stated earlier, respondents also indicated that the textbook played a key role in the development of their curriculum. This is not surprising, because research has shown that textbooks are often used as the primary source of information in the science classroom (Harms \& Yager, 1981; Stake \& Easley, 1978; Yore \& Denning, 1989). Yager (1983) has documented the textbook dependence of science instruction, reporting that more than $90 \%$ of all American science teachers use the textbook $95 \%$ of the time and that generally a single textbook guides the curriculum. However, respondents in the current study also believed that they had the freedom to develop their own curriculum with little or no outside influence.

This becomes more disturbing considering that an overwhelming number of the respondents believed that their textbooks do not adequately cover social issues. This could lead one to the idea that teachers see a textbook as a source of content and not a source of social issues. Further data supports a conflict in the teachers' beliefs and their reported actions. Most notably, more than $70 \%$ of the respondents strongly agreed or agreed that social issues should be integrated into the curriculum and $56 \%$ of the teachers indicated that they incorporate social issues into their curriculum. This alone seems ironic, because almost $69 \%$ indicate that 


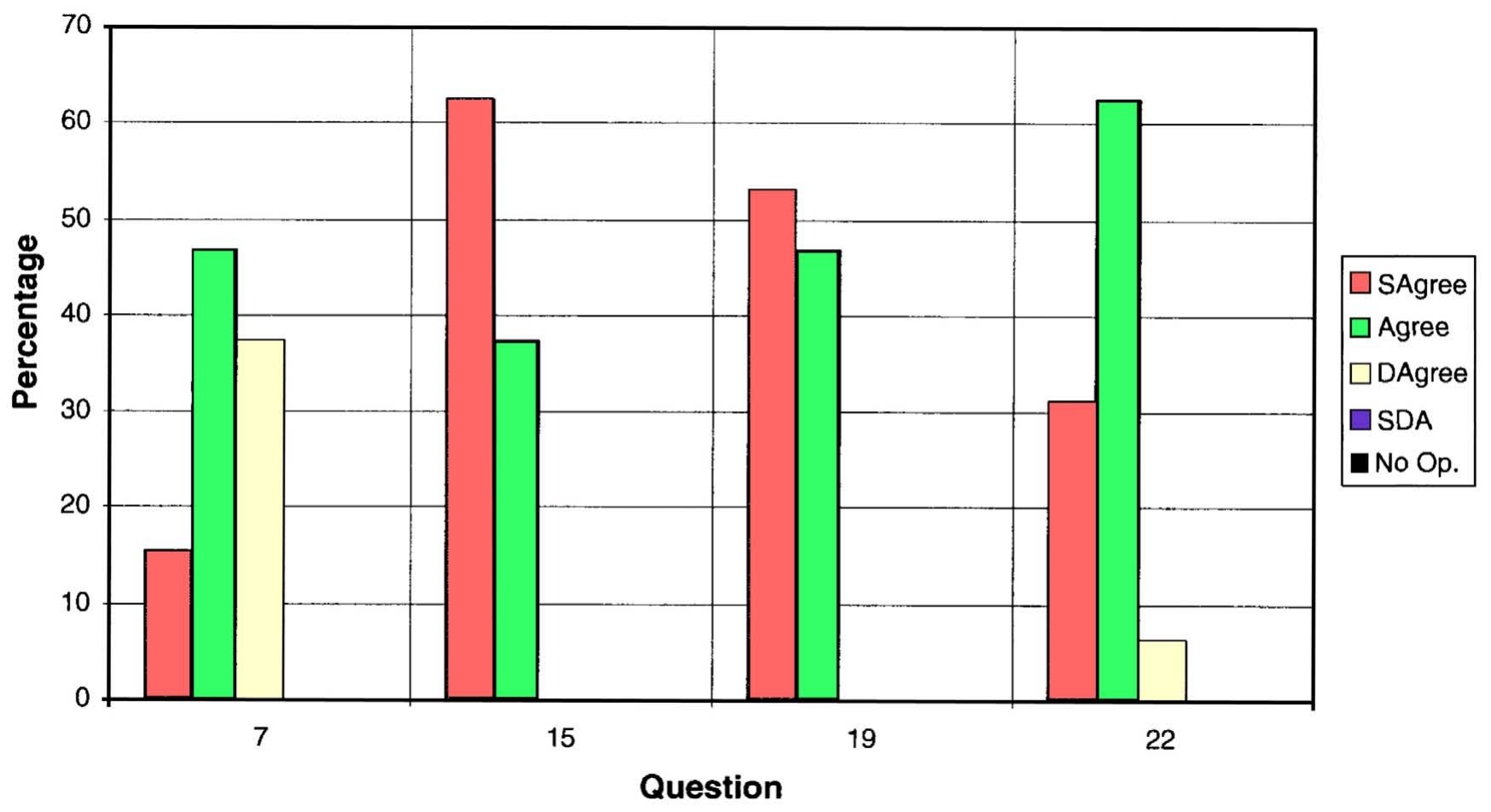

Figure 3. Beliefs About Social Issues

SAgree = strongly agree, DAgree = disagree, SDA = strongly disagree, and No Op. = no opinion. Statements are as follows:

7. Social issues such as abortion rights, censorship, land use, and so forth should be taught in the classroom.

15. Courses such as environmental studies, current events, and so forth should be taught in school systems today.

19. Global issues such as ozone depletion and land use should be discussed in the classroom.

22. I would feel comfortable discussing HIV/ AIDS or other social issues with my class.

Table 4. Beliefs About Social Issues

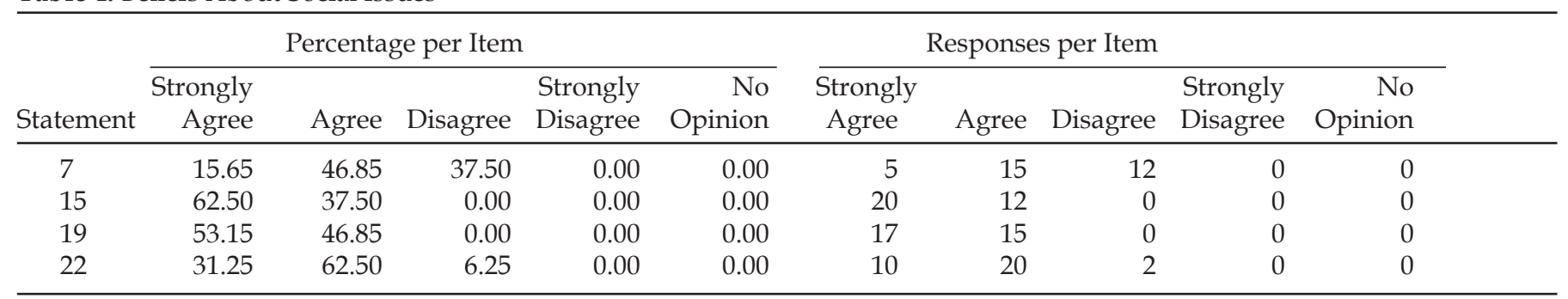

Statements are as follows:

7. Social issues such as abortion rights, censorship, land use, and so forth should be taught in the classroom.

15. Courses such as environmental studies, current events, and so forth should be taught in school systems today.

19. Global issues such as ozone depletion and land use should be discussed in the classroom.

22. I would feel comfortable discussing HIVIAIDS or other social issues with my class.

they use a textbook that does not adequately incorporate the study of social issues. Why is it that teachers report a belief in social issues as an important part of the curriculum, yet verify that the sources of curricular materials that they use do little to enhance the development of curriculum that incorporates social issues, even though they have the freedom to do so? Although this alone does not verify that social issues are not being taught, it does point out one area where a conflict or a possible constraint might exist in limiting the implementation of the STS reform: Namely, the reliance on a textbook as the source of their curriculum and the belief that content is the most important aspect in the science classroom.

In addition to the reliance on the textbook as the major source for the curriculum, it is also interesting to note where teachers report they obtain information about social issues. As Aikenhead (1988) shared, 73\% of 


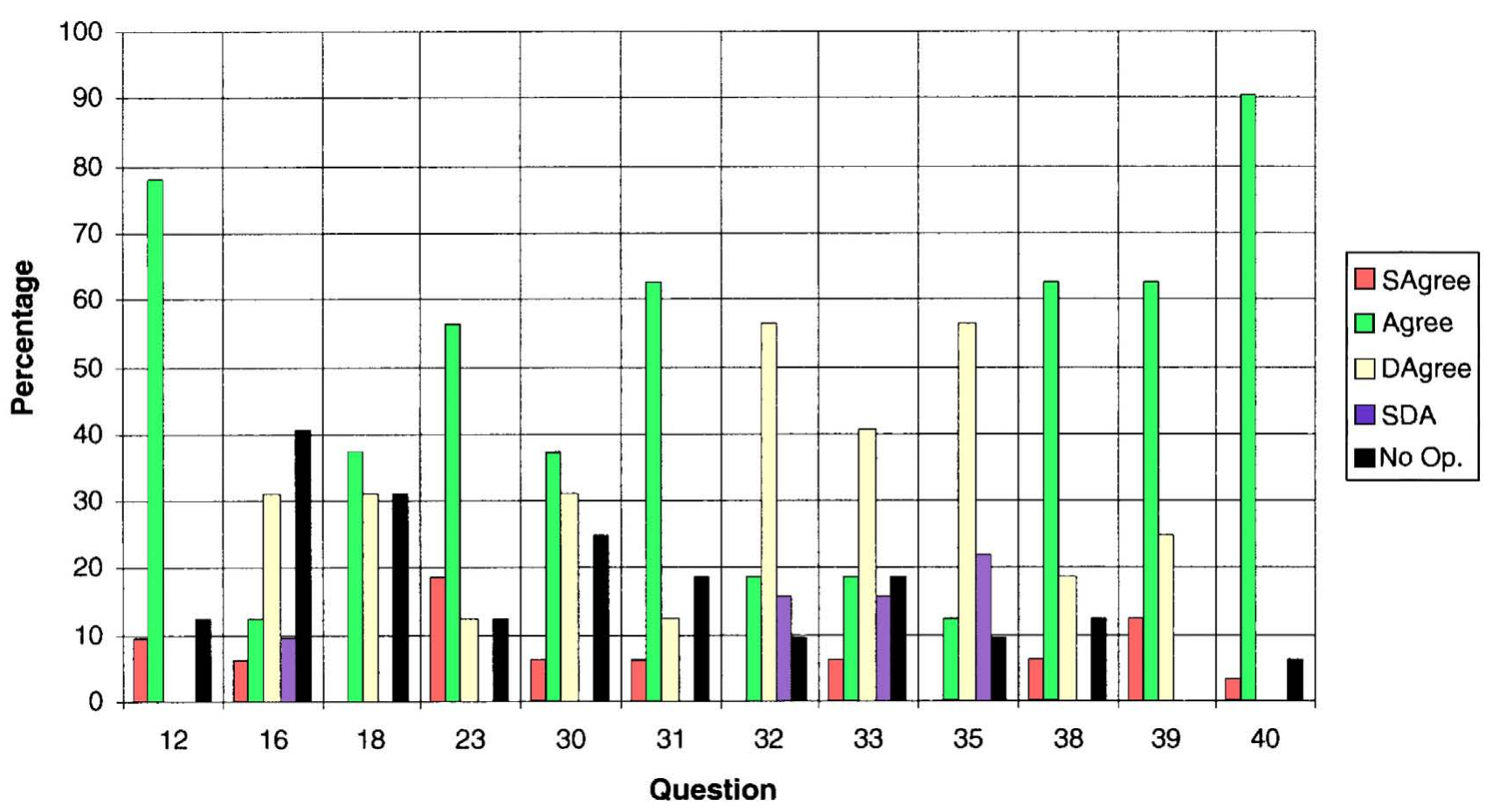

Figure 4. Outside Influences/Constraints

SAgree $=$ strongly agree, DAgree $=$ disagree, $\mathrm{SDA}=$ strongly disagree, and No Op. $=$ no opinion. Statements are as follows:

12. I feel that I am appreciated and respected by my superiors.

16. I am thoroughly supported by faculty and staff members on teaching social issues.

18. I feel that I would be supported by the parents of my students on teaching social issues in my classroom.

23. I feel that I have my principal's support when trying new ideas in my classroom such as the teaching of social issues.

30. I feel that the parents of my students would support my efforts to teach about social issues.

31. My coworkers would provide me with support in regard to teaching about social issues.

32. My preservice program prepared me for teaching about social issues.

33. In-service programs provided by my district or school provide me with valuable information and/or skills on social issues.

35. My principal has a lot of input into what I can teach in the classroom.

38. I involve the parents of my students in the educational process whenever possible.

39. I feel that parental approval of my teaching skill is important.

40. I respect my principal's authority.

the students get their information about scientists and the social technological contexts of science from television, films, magazines, and books. That is surprising, because at least in this study, teachers indicated that newspapers, television, radio, and personal experience were the places where they were most likely to receive information about social issues. Although the sources of information are most likely linked to the relative ease with which they could be accessed, it was disheartening to see that lectures/in-service/conventions ranked in the bottom half of their sources of information. And in fact, friends/acquaintances and family have approximately the same mean ranking as lectures/in-service/conventions.

In addition to beginning to understand the relationship in regard to teachers' beliefs on content and textbooks, more disturbing is the beliefs shared by teachers on their role in educating students about social issues. As noted previously, teachers indicate a belief that teaching social issues is important and that they indeed include social issues in their curriculum. However, teachers also indicate that they believe teachers bear too much responsibility for educating students about social issues. This is surprising because in this same survey nearly all of the teachers claimed that preparing or educating students to be productive citizens is an important goal of education. There is, from the data, a clear picture that teachers' beliefs and actions may not be in sync. That is to say, the teachers reported that they believe in the need to teach about social issues yet repeatedly indicated that their own school curriculum does not include the study of social issues.

For example, teachers believe that they are competent to teach social issues, that they are adequately prepared to teach social issues, and have no definite anxiety about teaching social issues, yet the majority of the teachers 
Table 5. Outside Influences/Constraints

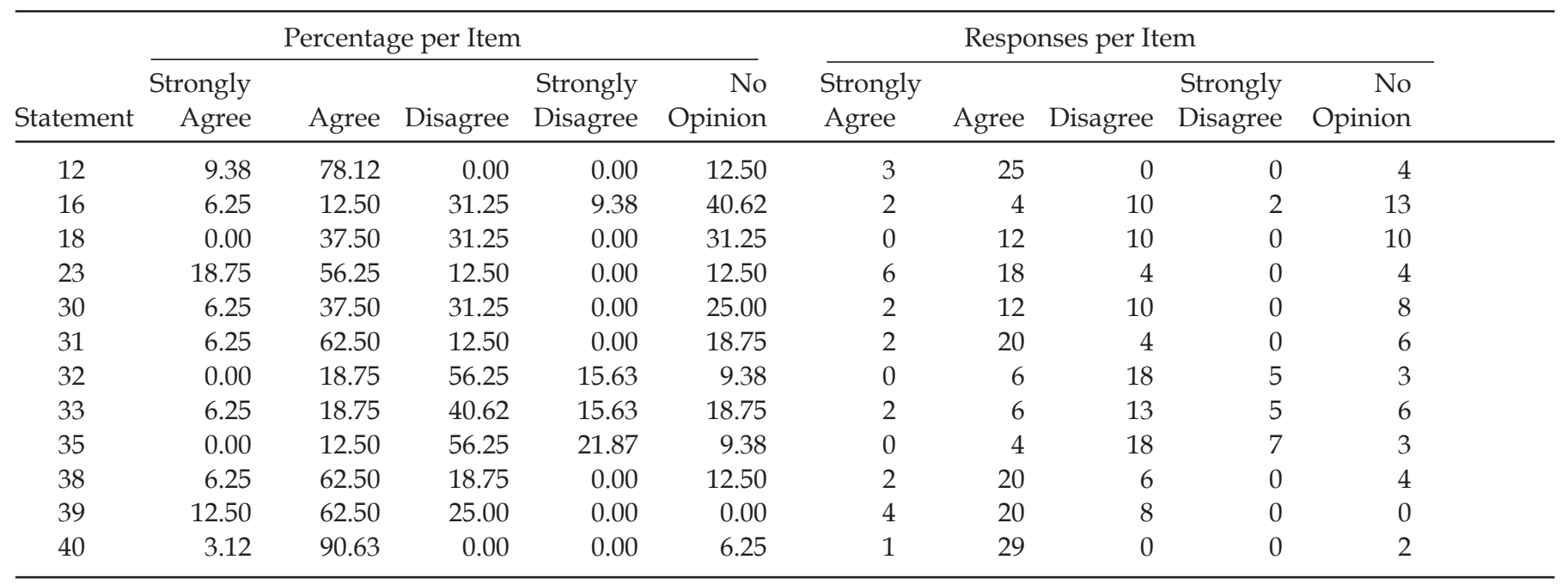

Statements are as follows:

12. I feel that I am appreciated and respected by my superiors.

16. I am thoroughly supported by faculty and staff members on teaching social issues.

18. I feel that I would be supported by the parents of my students on teaching social issues in my classroom.

23. I feel that I have my principal's support when trying new ideas in my classroom such as the teaching of social issues.

30. I feel that the parents of my students would support my efforts to teach about social issues.

31. My coworkers would provide me with support in regard to teaching about social issues.

32. My preservice program prepared me for teaching about social issues.

33. In-service programs provided by my district or school provide me with valuable information andlor skills on social issues.

35. My principal has a lot of input into what I can teach in the classroom.

38. I involve the parents of my students in the educational process whenever possible.

39. I feel that parental approval of my teaching skill is important.

40. I respect my principal's authority.

believe that teaching social issues would create controversy within the school system. Although this conflict or constraint comes to the surface, it would appear that there is much more here than just a fear of controversy. The teachers seem to have a belief in the value of teaching social issues and believe themselves able to do so, but do little to put this belief into practice.

It seems that a key and critical piece of information in this puzzle would be the role of others (administrators, faculty/staff, students, parents, and community members) in the support of teaching social issues. Most of the teachers felt that they had their principals' support for trying new ideas in their classrooms. These teachers also believed that their peers would support such reform efforts as the teaching of controversial issues. Despite this support, more than $30 \%$ of the respondents stated that other faculty and staff members do not support them when it comes to teaching controversial issues. Only $31 \%$ of the respondents indicated that they would be supported by the parents of their students on teaching social issues in the classroom. It is clear from this data that the teachers responding to the survey felt that the community in which they teach would at best only provide moderate support for the study of social issues in their science classroom. And in fact, the majority of the teachers believe that they have either low support or no support for the study of controversial social/technological issues from their community. This again is an additional piece to place in the puzzle as it concerns teachers' attempts to implement social issues into the science curriculum. If support is lacking, then your actions may be limited in terms of one's willingness to go it alone. The old axiom, "When in Rome, do as the Romans do" has significant meaning when one is placed in the culture of a school and community. In addition, the significance of canonical knowledge becomes more apparent when a teacher comes in contact with knowledge and beliefs that are accepted by the majority and then shared. Bruner's (1985) words are appropriate to reiterate here that we learn from the members of our culture how to understand the world and what is valued. It seems that the teachers in this study may have contradictions in their own beliefs about the teaching of social issues and those offered by the culture of the community and school. 


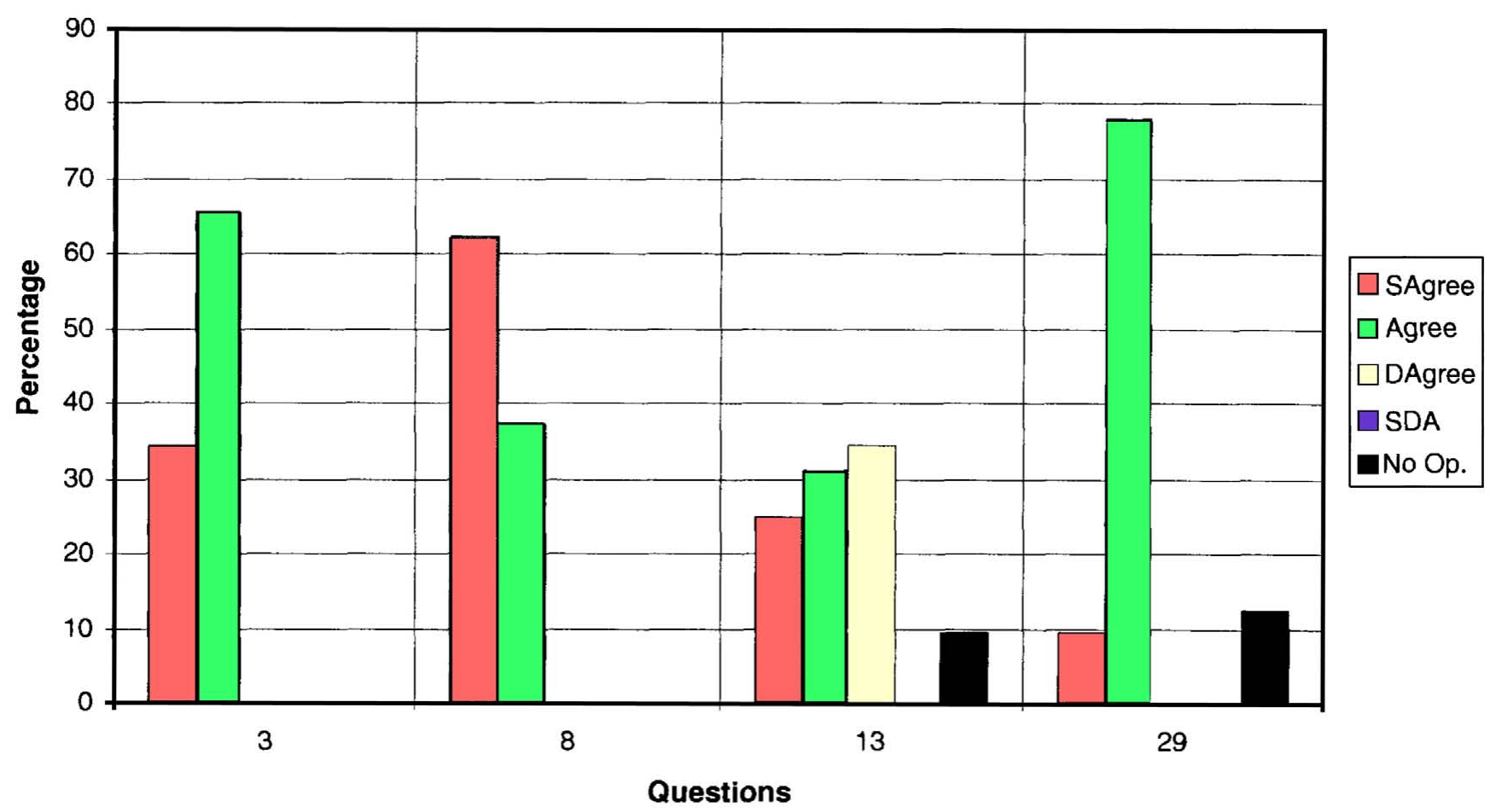

Figure 5. Teacher-Student Relationship

SAgree $=$ strongly agree, DAgree $=$ disagree, SDA = strongly disagree, and No Op. = no opinion. Statements are as follows:

3. I feel that I have a positive impact on my students' lives.

8. Teachers have an obligation to teach students how to become responsible and productive members of society.

13. My students feel that they can talk to me about anything.

29. Students want to learn about social issues.

Table 6. Teacher-Student Relationship

\begin{tabular}{|c|c|c|c|c|c|c|c|c|c|c|}
\hline \multirow[b]{2}{*}{ Statement } & \multicolumn{5}{|c|}{ Percentage per Item } & \multicolumn{5}{|c|}{ Responses per Item } \\
\hline & $\begin{array}{r}\text { Strongly } \\
\text { Agree }\end{array}$ & Agree & Disagree & $\begin{array}{l}\text { Strongly } \\
\text { Disagree }\end{array}$ & $\begin{array}{r}\text { No } \\
\text { Opinion }\end{array}$ & $\begin{array}{c}\text { Strongly } \\
\text { Agree }\end{array}$ & Agree & Disagree & $\begin{array}{l}\text { Strongly } \\
\text { Disagree }\end{array}$ & $\begin{array}{r}\text { No } \\
\text { Opinion }\end{array}$ \\
\hline 8 & 62.50 & 37.50 & 0.00 & 0.00 & 0.00 & 20 & 12 & 0 & 0 & 0 \\
\hline 13 & 25.00 & 31.25 & 34.37 & 0.00 & 9.38 & 8 & 10 & 11 & 0 & 3 \\
\hline 29 & 9.38 & 78.12 & 0.00 & 0.00 & 12.50 & 3 & 25 & 0 & 0 & 4 \\
\hline
\end{tabular}

Statements are as follows:

3. I feel that I have a positive impact on my students' lives.

8. Teachers have an obligation to teach students how to become responsible and productive members of society.

13. My students feel that they can talk to me about anything.

29. Students want to learn about social issues.

Finally, teachers in this study indicated that they believe their preservice education did not prepare them for teaching social issues. In addition, teachers believe that their schools' in-service programs do not provide adequate information or skills necessary to teach social issues. This is more than a little disturbing, because an emphasis of the National Standards and the NCATE recommendations clearly indicate that "science in personal and social perspectives ... are an important purpose of science education" (NRC, 1996, p. 107) and "the program prepares candidates to relate science to the daily lives and interests of students and to a larger framework of human endeavor and understanding" (NRC; NSTA, 1998). Again, as with each piece of evidence gathered in this study, this alone is not enough to generalize and state that this is the reason that social issues are not taught. However, this along with other aspects shared from the study can provide us with insights as 


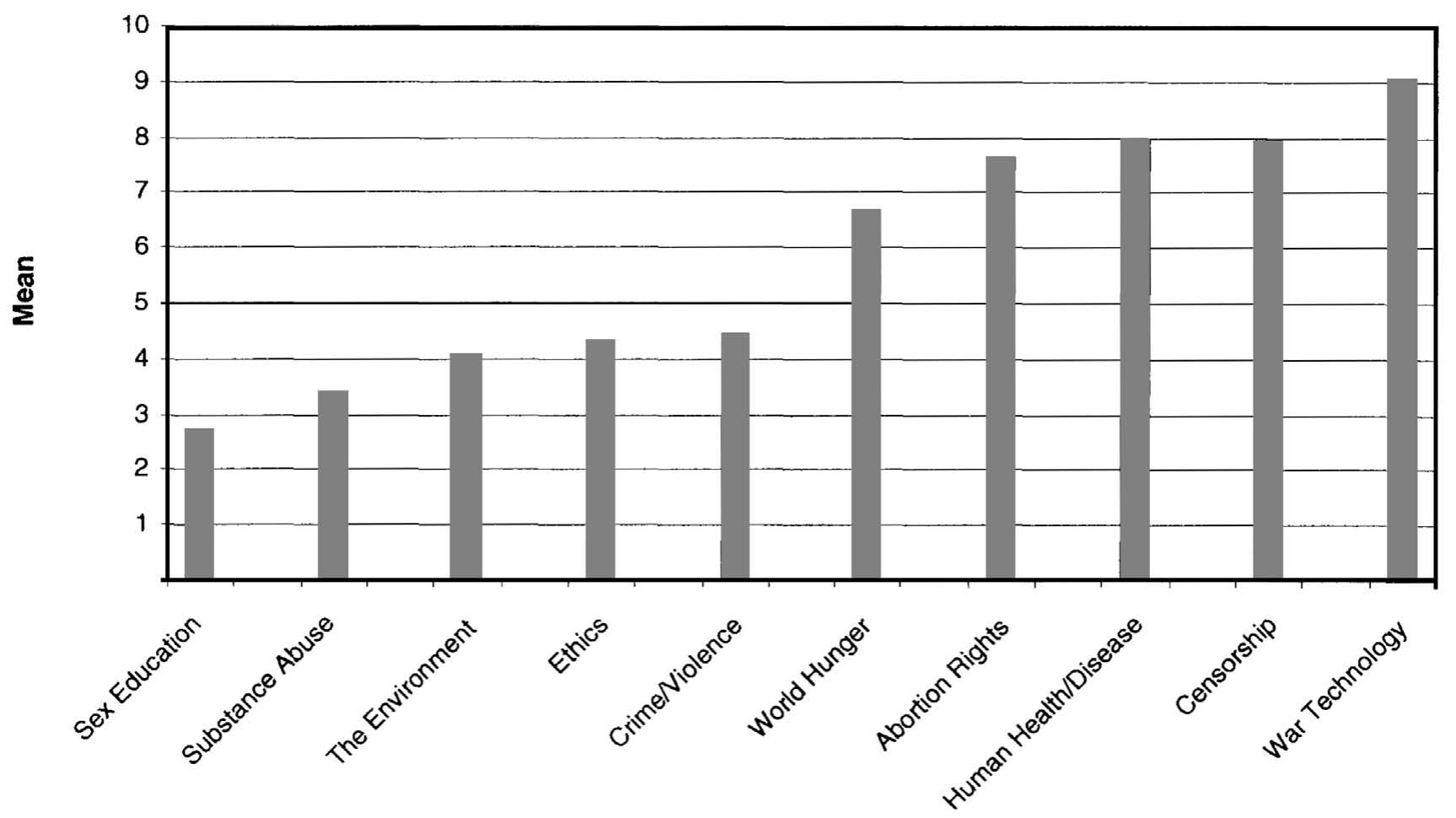

Figure 6. Ranking Social Issue: Most (1) to Least (10) Attention

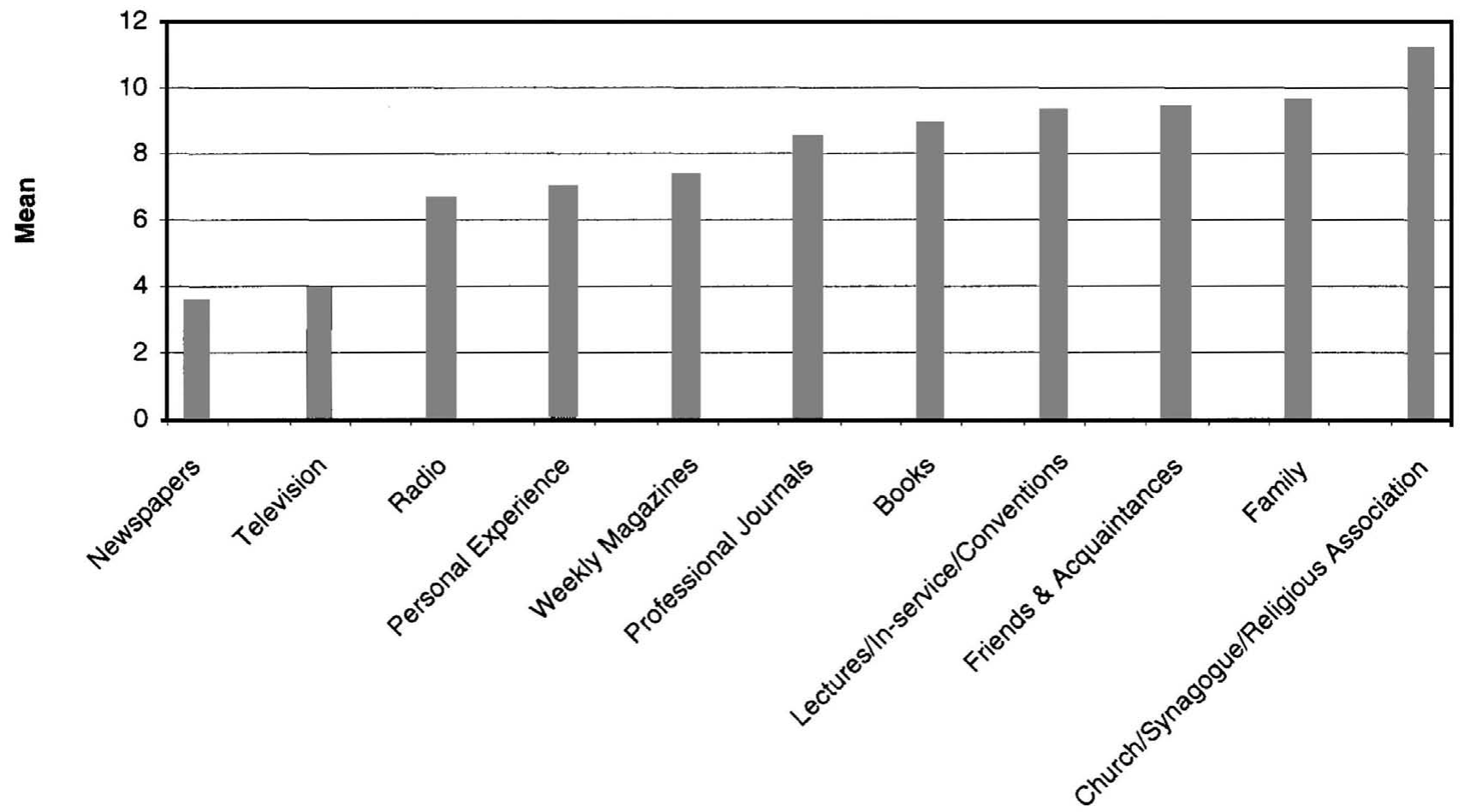

Figure 7. Sources of Information: Primary (1) to Least (10) Important Source

to why teachers may not be implementing or are struggling to implement social issues in their curriculum. It is also interesting to note that the teachers believed them- selves to be knowledgeable and able to teach social issues, but preservice and in-service programs did not prepare them well. This raises yet another question re- 


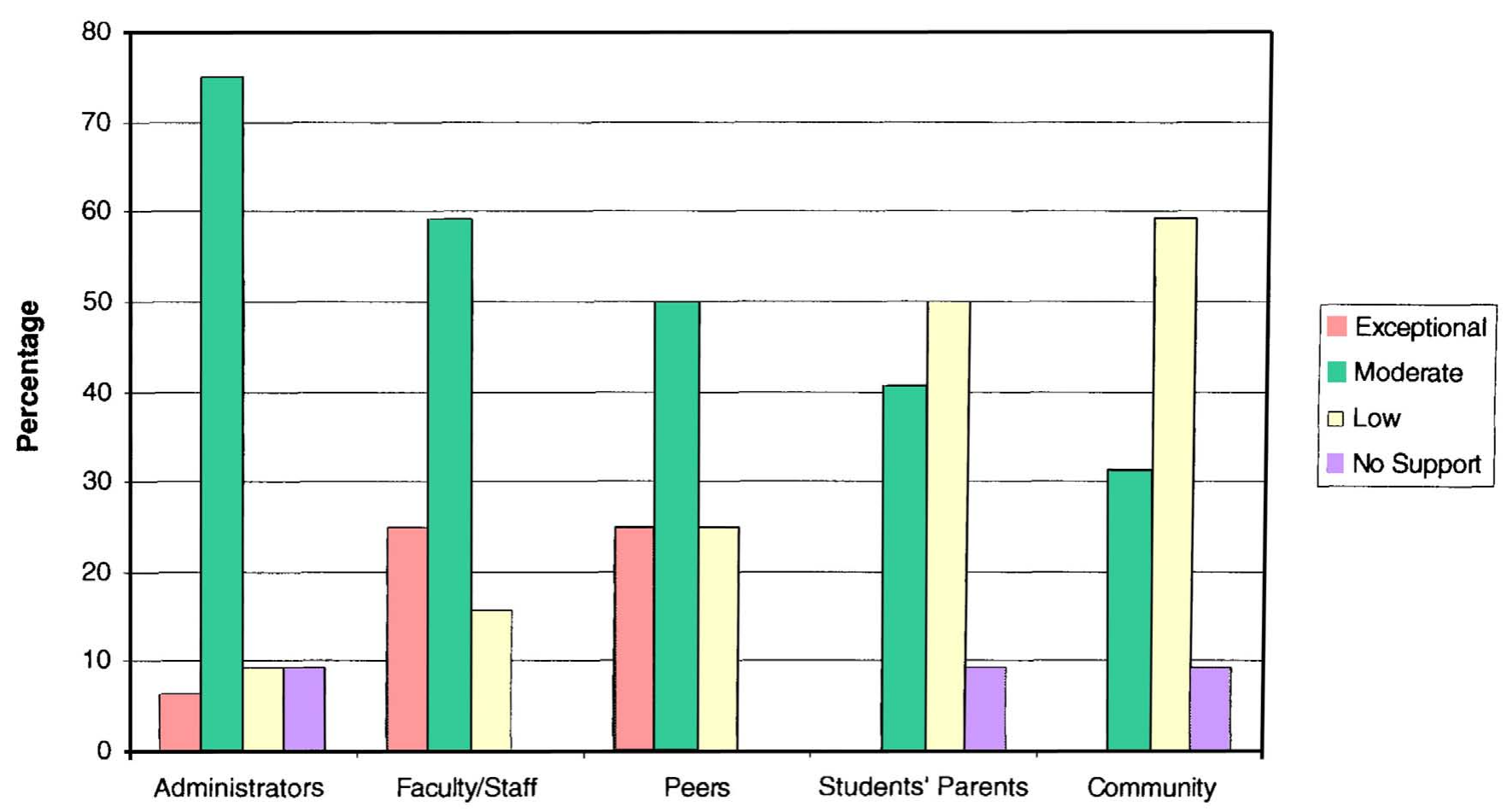

Figure 8. Support by Administrators, Faculty/Staff, Students' Parents, and the Community

Table 7. Means for Social Issues: Ranking From Most (1.00) to Least (10.00) Attention

\begin{tabular}{lc}
\hline Category & Mean \\
\hline Sex education & 2.73 \\
Substance abuse & 3.40 \\
The environment & 4.06 \\
Ethics & 4.33 \\
Crime/violence & 4.46 \\
World hunger & 6.66 \\
Abortion rights & 7.66 \\
Human health/disease & 8.00 \\
Censorship & 8.00 \\
War technology & 9.06 \\
\hline
\end{tabular}

garding where teachers gain their knowledge about how to implement social issues. Is it from the sources they cited (e.g., newspapers, radio, television, etc.)? Is it from their friends or family? This is one more aspect of the study that suggests a discrepancy between teachers' beliefs about themselves and their beliefs and perceptions about other aspects of teaching social issues.

From the data collected in this study, we can discern that teachers believe that they are capable of teaching controversial social/technological issues. Yet they also
Table 8. Means for Sources of Information on Social Issues: Ranking From Primary (1.00) to Least Important (12.00) Source

\begin{tabular}{lr}
\hline Category & Mean \\
\hline Newspapers & 3.58 \\
Television & 4.00 \\
Radio & 6.66 \\
Personal experience & 7.00 \\
Weekly magazines & 7.33 \\
Professional journals & 8.50 \\
Books & 8.91 \\
Lectures/in-service/conventions & 9.33 \\
Friends and acquaintances & 9.41 \\
Family & 9.66 \\
Church/synagogue/religious association & 11.25 \\
\hline
\end{tabular}

show a concern that their preservice and in-service education did not prepare them to teach social issues. They also believe that they have freedom to develop their own curriculum, but rely almost exclusively on the textbook for the curriculum in their science classrooms. They believe that they have the support of administrators to try new ideas, but also believe that the support of faculty/staff, parents, and community members to delve into controversial issues in the science classroom is lacking. As indicated by the respon- 
Table 9. Support by Administrators, Faculty/Staff, Students' Parents, and the Community

\begin{tabular}{|c|c|c|c|c|}
\hline & Exceptional & Moderate & Low & No Support \\
\hline Administrators & 6.25 & 75.00 & 9.37 & 9.37 \\
\hline Peers & 25.00 & 50.00 & 25.00 & 0.00 \\
\hline Students' parents & 0.00 & 40.63 & 50.00 & 9.37 \\
\hline Administrators & 2 & 24 & 3 & 3 \\
\hline Faculty/staff & 8 & 19 & 5 & 0 \\
\hline Peers & 8 & 16 & 8 & 0 \\
\hline Students' parents & 0 & 13 & 16 & 3 \\
\hline Community & 0 & 10 & 19 & 3 \\
\hline
\end{tabular}

dents, some major reasons appear as to why teachers seem to be reluctant to discuss or teach about controversial issues. They include:

1. Teachers believe that they lack the outside support from parents and their community to do so.

2. In some cases, teachers also believe that they lack the internal support of faculty and staff when attempting to implement controversial issues into their science curriculum.

3. It would seem that possible cultural expectations of the community might influence the development of teachers' curriculum, even though teachers believe that they have the freedom in their classrooms to develop what they deem as necessary.

4. Teachers are presenting information to students based on textbooks that they believe are deficient in the area of social issues.

5. Teachers in this study reported that more than $65 \%$ of them use the textbook as the major guide for their curriculum.

6. The selection of textbooks and the overwhelming use of these could also be linked to the expectations of the norms of the community in which the teachers practice.

7. Teachers are potentially creating a false dichotomy between content and social issues.

8. Teachers believe that neither in-service nor preservice education provides adequate support for the understanding of social issues.

9. Teachers rely on easily accessible sources for their information on social issues.

Although we did not observe these teachers in their classrooms, it would appear that there is a contradiction in their beliefs and perceptions of self regarding social issues and what actually is accomplished in the classroom. This becomes relevant because the National Science Standards clearly indicate that the teaching of social issues (STS) should be part of the curriculum. Project 2061 (American Association for the Advancement of Science, 1989) and Benchmarks also underscore the necessity for the understanding of social issues in relation to science. Furthermore, the NSTA (1998) guidelines for teacher preparation clearly indicate that teachers should be prepared to teach social issues in science classrooms. If science educators are serious about the implementation of STS-type topics into the science curriculum, more needs to be done to understand the relationship of taboos and norms in communities, schools, and classrooms. In relation to this, it would be important to examine the myths that a culture projects onto teachers and the inherent expectations that communities have for the performance of the curriculum in public schools. For as Bandura (1986) indicates, "Of the many cues that influence behavior, at any point in time none is more common than the action of others" (p. 206).

\section{References}

Aikenhead, G. (1990). Consequences to learning science through STS: A research perspective. Paper presented to the British Council's "Science, Technology and Society Education" course, Department of Education Studies, Oxford University.

Aikenhead, G S. (1985). Collective decision-making: Implications for teaching science. Bulletin of Science, Technology \& Society, 5(2), 117-129.

Aikenhead, G. S. (1988). An analysis of four ways of assessing student beliefs about STS topics. Journal of Research in Science Teaching, 25(8), 607-6301 
Aikenhead. G. S. (1989). Views on science-technology-society, form CDN.mc5-Canadian standard responses. Saskatoon, Saskatchewan: Department of Curriculum Studies, University of Saskatchewan.

American Association for the Advancement of Science. (1989). Project 2061: Science for all Americans (Publication No. 8901s). Washington, DC: AAAS.

Bandura, A. (1986). Social foundations of thought and action: A social cognitive theory. Englewood Cliffs, NJ: Prentice Hall.

Benson, G. (1989). Epistemology and science curriculum. Journal of Curriculum Studies, 21, 329-344.

Borphy, J. E., \& Evertson, C. M. (1981). Students' characteristics and teaching. New York: Longman.

Bragaw, D. (1993). Society, technology, and science: Is there room for another imperative? Theory into Practice: Science, Technology, Society: Opportunities, 31(1), 4-11.

Bruner, J. (1985). Vygotsky: A historical and conceptual perspective. In J. Wertsch (ed.), Culture, communication and cognition: Vygotskian perspectives (pp. 21-34). Cambridge, UK: Cambridge University Press.

Bybee, R. W. (1987). Science education and the science-technology-society (S-T-S) theme. Science Education, 71, 667-683.

Bybee, R. W. (1993). Reforming science education: Social perspectives and personal reflections. New York: Teachers College Press.

Bybee, R. W., \& Mau, T. (1986). Science technology related global problems: An international survey of science educators. Journal of Research in Science Teaching, 23, 599-618.

Gilliom, M. E., Helgeson, S. L., \& Zuga, K. F. (1992). The issue. Theory into Practice: Science, Technology, Society: Opportunities, 31(1), 1-3.

Harms, N. C., \& Yager, R. E. (1981). What research says to the science teacher. Washington, DC: National Science Teachers Association.

Hofstein, A., \& Yager, R. E. (1982). Societal issues as organizers for the science education in the 80 's. School Science and Mathematics, 82, 539-547.

Jackson, D. (1993). Two cases of implementing STS activities in the context of a traditional middle school life science curriculum: Same rules, different games. Paper presented at the annual National Association for Research in Science Teaching, Atlanta, GA.

Lawson, A. E., \& Worsnop, W. A. (1992). Learning about evolution and rejecting a belief in special creation: Effects of reflective reasoning skill, prior knowledge, prior belief and religious commitment. Journal of Research in Science Teaching, 29(2), 143-166.

McGinn, M. K., Roth, W. M., Boutonne, S., \& Woszczyna, C. (1995). The transformation of individual and collective knowledge in elementary science classrooms that are organized as knowledge-building communities. Paper presented at the annual meeting of the National Association of Researchers in Science Teaching, San Francisco.

McGinnis, R. J. (1993). STS from a taboo and Noa perspective. Paper presented at the annual National Association for Research in Science Teaching, Atlanta, GA.

Mitchener, C. P., \&Anderson, R. D. (1989). Teachers' perspec- tive: Developing and implementing an STS curriculum. Journal of Research in Science Teaching, 26(3), 351-369.

National and State Department of Education. (1996). National Assessment of Educational Progress (NAEP) 1996 mathematics report card for the nation and the states: Center for education statistics. Washington, DC: Department of Education.

National Research Council. (1996). National science education standards. Washington, DC: National Academy Press.

National Science Teachers Association. (1998). NSTA/NCATE standards for science teacher preparation. Online at http:// homepages.ius.edu/LZ/SGILBE01/web docs/nsta98.htm

O'Loughlin, M. (1990, April). Evolving beliefs about teaching and learning: The view from Hofstra University: A perspective on teachers' beliefs and their effects. Paper presented at the annual meeting of the American Educational Research Association, Boston.

Pedersen, J. E. (1992). The effects of cooperative controversies, presented as STS issues, on anxiety and achievement in secondary science classrooms. School Science and Mathematics Journal, 92(7), 374-380.

Pedersen, J. E., \& Totten, S. (1994). Students' sources of information and social issues, their level of participation in social action, schools' preparation of students to address social issues, and students' personal concerns relating to social issues: A national survey of high school students. Paper presented at the annual National Association for Research in Science Teaching, Anaheim, CA.

Penick, J. E., \& Yager, R. E. (1986). Science education: New concerns and issues. Science Education, 70, 427-431.

Rachlin, J. (1988, December). Finding the right formula: Innovative cures for the sad state of science education. U.S. News \& World Report, pp. 59-61.

Roy, R. (1985). The science/technology/society connection. Curriculum Review, 24(3), 12-14.

Rubba, P. A., \& Wiesenmayer, R. L. (1985). A goal structure for pre-college STS education: A proposal based upon recent literature in environmental education. Bulletin of Science, Technology \& Society, 5(6), 573-580.

Ryan, A. G. (1987). High school graduates' beliefs about S-TS: The characteristics of scientists. Science Education, 71, 489510.

Simmons, P. (1993). Science/technology/society: Multiple research perspectives. Paper presented at the annual National Association for Research in Science Teaching, Atlanta, GA.

Stake, R. E., \& Easley, J. A. (1978). Case studies in science education. Urbana: Center for Instructional Research and Curriculum Evaluation, University of Illinois.

Tobin, K. (1991). Making sense of science teaching. Paper presented at the annual meeting of the National Association for Research in Science Teaching, Lake Geneva, WI.

Tobin, K. (1994). Research on instructional strategies for teaching science. In D. Gable (Ed.), Handbook of research on science teaching (45-93). New York: Macmillan.

Tobin, K., Tippins, D., \& Hook, K. (1992). The construction and reconstruction of teacher knowledge. Paper presented at the annual meeting of the American Educational Research Association, San Francisco. 
Totten, S. (1992). Educating for the development of social consciousness and social responsibility. In Social issues in the English classroom. Urbana, IL: National Council of Teachers of English.

Totten, S., \& Pedersen, J. E. (1994). The status of the study of social issues in the high school social studies classroom: A study. Inquiry in Social Studies, 32(1), 22-46.

Toulmin, S. (1979). Can science and ethics be reconnected. Hastings Center Report, 28-34.

Yager, R. E. (1983). The importance of terminology in teaching K-12 science. Journal of Research in Science Teaching, 20, 557-558.

Yager, R. E. (1988). A new focus for school science: S/T/S. School Science and Mathematics, 88, 181-189.

Yore, L. D., \& Deming, D. (1989, March/April). Implementing change in secondary science reading and textbook usage: A desired image, a current profile and a plan for change. Paper presented at the 62nd Annual Meeting of the National Association for Research in Science Teaching, San Francisco.

Zoller, U., Donn, S., Wild, R., \& Beckett, P. (1991). Teachers' beliefs and views on selected science-technology-society topics: A probe into STS literacy versus indoctrination. Science Education, 75(5), 541-561.
Zoller, U., Dunn, S., Wild, R., \& Beckett, P. (1991). Students' versus their teachers' beliefs and positions on science/technology/society oriented issues. International Journal of Science Education, 13, 25-35.

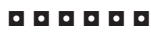

Jon E. Pedersen is currently a professor of science education at the University of Oklahoma. He specializes in the study of science/technology/societal issues and understanding preservice teachers' perceptions of teaching science.

Samuel Totten is currently a professor of curriculum and instruction at the University of Arkansas at Fayetteville. His main area of research focuses on the theory, research, and practice vis-a-vis the intervention and prevention of genocide. He has also written extensively on the inclusion of social issues across the curriculum, and on Holocaust and genocide education. 